\title{
Counselling and Moral Education: A Panacea in Curbing the Increasing Trends of Agitation in Nigeria
}

\author{
Article by Sr. Victoria Uzoamaka Ezeh \\ Ph.D in Guidance and Counseling Psychology, Texila American University, Nigeria \\ Email: sistervictoriaeze@texilaconnect.com
}

\begin{abstract}
Education has been the bedrock of national development since inception but in recent times Nigeria has witnessed a lot of agitations in nearly all the geo-political zone of the federation which has stagnated national unity. This increasing trend of agitations has taken another shape especially in the Niger delta region and other parts of the country which has left political unrest, social, economic and psychological losses and pains. This paper therefore explored frustration aggression theory and consent that aggression is always based on frustration which is the justification for the increasing trends of agitations in Nigeria. Also this paper, examined the different group of agitators based on their demand and then focuses on counselling and moral education which is a universal permanent and pervasive phenomenon in human society as well as the earliest factors that influence human life as a panacea in curbing the increasing trends of agitations in Nigeria. The concept of counselling and moral education was explained and recommendation was also given.
\end{abstract}

Keywords: moral education, counselling, agitation, youth, Nigeria and violence.

\section{Introduction}

Nigeria is a plural and heterogeneous state with over 350 ethnic groups with the Hausa-Fulani, Yoruba and Igbos making the majority tribes (The New York Times, 2012). This explains the Nigerian conundrum though with a federal structure which was until 1914 a diffusedly independent groups which occasionally relates with one another is a peripheral state with over 400 languages (Egbe, 2004) and about 190 million people, resource allocation has always been centralized thereby causing frustration, aggression and hunger for the control of the centre. A society, made up with diverse belief systems, customs and institutions where violence is inevitable as a result of conscious opposition to one or more groups because these groups or persons appear to have incompatible interest. Since independence in 1960, the country has witnessed a lot of violent eruption, ethno religious crisis, the Biafra war and general insecurity in nearly all the state of the federation. But more recently, the sporadic agitations in nearly all the geo-political zone of the federation have resulted in the operation of several militia groups. Notable among these groups are the Niger Delta Avengers, Boko Haram and Indigenous people of Biafra among others. The operation of this militia groups constituted by large number of youth has coursed a lot of havoc in the country leading to social and economic dislocation, psychological losses, destruction of property, kidnapping and all order forms of maladies.

Globally youth are faced with enormous problems. Atwater (1988) argues that the adolescent stage of life is marked by emotional development that includes mood swings, enthusiasm, tenderness, cruelty, curiosity and apathy. This however explains why adolescents out of tension, frustration and aggression often indulge in violent act which if not checkmate could leads to formation of group agitations. This adolescents are not matured enough to critically evaluate baffling situations they continuously faced which means they need somebody to help them in the solution of problems and thus avoid tensions, frustration and conflicts. The youth must know their capabilities and potentialities, especially in areas that are crucial for the realisation of objectives in life. Their goals, aspirations and expectations are to be shaped accordingly. Corey (1991) holds that counselling is a 
service designed to help an individual to analyze himself/herself by relating his capabilities, achievements, interests and mode of adjustment. As explained by Biswalo (1996), the need for counselling services today could be due to the ever- growing complexity of the society and people have to learn how to cope with the upcoming challenges. Morally, adolescent need to be taught the right conducts, not only in their immediate social relations, but also in their dealings with their fellow citizens and with the whole of human race. Counselling services and moral education are imbedded in every educational system but lack of adequate attention by the government over the years has exposed these adolescent to society where violence and agitations is the only way to dispose their demand and grievance. Consequently, several strategies and measures have been adopted by the federal government which includes dialogue, amnesty and military interventions over the years in response to the request of this militia groups has yielded insignificant results. Therefore it is against this background that this paper suggests the use of counselling and moral education as a panacea in curbing the increasing trends of agitations in Nigeria.

\section{Conceptual and theoretical explanation}

\section{Counselling}

Counselling is a learning process in which a counsellor helps an individual or individuals learn, understand themselves and their environment and be in a position to choose the right type of behaviours that will help them develop, grow, progress, ascend, mature and step up, educationally, vocationally and socio personally (Egbo, 2013). Mutie and Ndambuki (2004) assert that counselling service is the brain and heart of the guidance programme. Thus counselling represents a part of the total process of guidance which is helping individuals, achieve the self- understanding and selfdirection necessary to make the maximum adjustment in a particular environment. Corey (1988) regards counselling as a process which occurs in one to one relationship between an individual troubled by problems with which he cannot cope with and a professional worker whose training and experiences have qualified him to help others reach solution to personal needs. Okoye (1990) viewed counselling as an interactional relationship designed to facilitate the personal development of information leading to effective decision making and awareness of the self.

\section{Moral education}

Etymologically, the word moral comes from a Latin word "mos or moris meaning the code or customs of a people, the social glue that defined how individuals should live together. Moral education is not a new idea; it is as old as society and education. It addresses ethical dimensions of the individual and society and examines how standard of right and wrong are developed. According to New Encyclopaedia Britannica Vol. 6, "Moral education is a designed moral value that guides people and in learning them towards their eventual role in the socieff. While Vol. 8 of the New Encyclopaedia Britannica define moral education as the development of sense of moral sensitivity and duty towards people and state. Fafunwa (1976) defined moral education as the inculcation of desirable values, norms, attitudes approved by the society in order to have good citizens in the future. In the light of the above definition, moral education is the key to the general sustenance of national integration and social orderliness. Moral education teaches core moral values, such as honesty and responsibility, care, etc and helps to raise morally responsible and self-disciplined citizens. Problem solving, decision-making and conflict resolution are also important parts of developing good moral character. Thus, to educate a person in mind and not in morals is to educate a menace in society (Omoregbe, 2000).

\section{Frustration aggression theory}

The frustration-aggression theory is associated with works of John Dollard et al (1939), the core assumption of which is that "aggression is based on frustration and this frustration always leads to aggression" (1939). Dollard et al. (1939) posited "that the occurrence of aggressive behaviour always 
presupposes the existence of frustration and, contrariwise, that the existence of frustration always leads to some form of aggression”. This theory presents the idea of relative deprivation as a perceived disparity between value expectation and value capabilities. Or the lack of a need satisfaction defined as a gap between aspiration and achievement (MidIarsky, 1975). Simply put, when there is a gap between the level of value expectation and the level of value attainment, due to lack of capability to establish a congruence between both levels, tension builds up due to the pressure of an unfulfilled aspiration or an unsatisfied urge or need. This, when not arrested in time, leads to frustration. Frustration, when it builds up, leads to the rising up of suppressed emotions of anger, which is often directed against the party considered to be the source of deprivation of satisfaction. This strong emotion finally finds an outlet through aggressive and invariably violent disposition towards the environment. The increasing trends of agitations by several militia groups against the government in Nigeria are viewed in this perspective. This however, is perceived to be of sufficient generality to provide a basis for the explanation of virtually all forms of agitations and aggressive behaviour which is the appropriate description of the increasing trends of agitations in Nigeria.

\section{Trend of agitations in geo political zone of nigeria}

Over the years there have been several militia groups agitating for one course or the other in all geo-political zone of the federation. But for the focus of this paper, the more recent trend of militia group from the south-south, south-east and north-east shall be considered.

\section{South-South}

The Niger Delta is one of the largest deltas in the world, probably the third largest on earth. The region is regarded as one of the nine most difficult deltas of the world comparable to the Mekong, the Amazon and the Ganges. It is situated in the central part of southern Nigeria. It lies within latitudes 4 degrees north to 6 degrees north, and longitude 5 degrees east to 8 degrees east (Azaiki, 2007: 1; Ile \& Akukwe, 2001). The area has a population of about twenty five million people, according to the 2006 national census figures (National Bureau of Statistics, 2006) and more than forty ethnic groups with links to the linguistic groups of Ijaw, Edo, Igbo, Efik, Ibibio and Oron. "It is rich in both renewable and non renewable natural resources such as oil, gas, bitumen, etc, accounting for $95 \%$ of the total revenue for the Nigerian government, generated from oil and gas exploration and $80 \%$ of national wealth” (Brisibie, 2001: 1; Tell, 2008: 33).

The combination of the activities of the oil companies and the government led to emergence of various armed groups operating under such names as Egbesu Boys, Movement for the Survival of the Ijaw Ethnic Nationality (MOSEIN), Joint Revolutionary Council (JRC), Arogbo Freedom fighters, Niger Delta Volunteer Force, the Movement for the Emancipation of the Niger Delta (MEND) and Niger Delta Avengers (NDA) among others. Their youths had drawn both local and international attention to their deplorable situation through their restiveness. This explains the attack on oil pipelines in the region which has created instability and has eating deep into the wealth of the nation. Their agitation is primarily based on quest for resource control as a result of oil discovery in the region while the violence in Niger Delta has its roots in the increasing protest of the region against their political, economic and environmental disenfranchisement (Kelly, 2008).

\section{North-East}

The emergence of Boko Haram is in the north-east is traceable to the blistering preaching of Mallam Abubakar Kilakam an indigene of Niger Republic resident in Maiduguri, Borno state. He propagated the anti- government message that led to his arrest and eventually deported to Niger Republic. The idea (Boko Haram) activity has been operating covertly for several years even before the emergence of late Mohammed Yusuf. Who it seems only met a fertile ground and capitalized on it to spread his gospel. Boko Haram sect derives its message largely from the ideology of one of the world terrorist groups Al-qaida (Omipidan, 2013). The philosophy of the sect is rooted in the practice of orthodox Islam. Orthodox Islam in their interpretation abhors Western education and the civil 
service bureaucratic system. This explains why the sect is popularly known as the Boko Haram, literally meaning 'Western education is a sin' (Boyle, 2010). The agitation by Boko Haram for the imposition of Shariah Penal code in the 36 states of the federation is primitive and unconstitutional as Nigeria is a secular state. The sect strongly advocate for the abrogation of any form of western education and culture generally and it draws its members mainly from disaffected youths and unemployed graduates, including former Almajiris (Street Children) who migrated from the rural areas to urban areas in search of better means of livelihood or to study under renowned Islamic teachers in cities like Kano, Zaria, Kaduna, and Maiduguri. The sect also has some well educated, wealthy and influential people as members. The sect is estimated to have over 280000 members across the 19 states of northern Nigeria, Niger Republic, Chad and Sudan. There demand has led to several activities like kidnappings, bombings and suicide attacks at both government and religious institutions that parade a huge number of people at a time. Since its military operation in 2009, about 17,000 people have been killed especially in the north-eastern Nigeria (Qaqar, 2012).

\section{South-East}

Since after the Biafra war, several groups have emerged in the south-east regions which are Movement for the Actualization of the Sovereign State of Biafra (MASSOB), Biafra Zionist Movement (BZM) and Indigenous people of Biafra (IPOB) among others. Generally the Igbos have craved for a just society where every ethnic groups can compete favourably for political power and where economic resources is equitably distributed through non- violence. In 1999, Ralph Uwazuruike formed a militia group called MASSOB which embarked on several demonstrations and also established a radio station in the US for the purposes of reaching out to Igbos in the Diasporas and attracting international attentions (TELL, 2004 in Ojukwu, 2009b). In 2012, another group called the BZM founded by a United Kingdom- based lawyer, Benjamin Onwuka claimed that an application has been sent to the UN for an observer status for the Republic of Biafra on the ground that the security of lives and property, practice of religion and freedom of Association of the Biafra People are no longer guaranteed in the entity called Nigeria, hence the call for an independent state on 5th November 2012 (Uzodima, 2014). Presently in south-east this recent agitations are from the IPOB led by Nnamdi Kanu, a British- Nigerian. Their claims are that the present administration have hounded and short-changed the Igbos in the scheme of things causing disharmony hence the call for a divided Nigeria. This is informed by the incessant hardship, lack of holistic development in the socioeconomic landscape of Nigeria, lack of youth employment, corruption in high offices and economic regression. Though it claimed to have existed since 2012 by a group of people from the South-South and South-east regions of the country in London, nothing was heard from them until the inauguration of President Buhari.

\section{Counselling and moral education as a panacea in addressing the increasing trends of agitations in nigeria}

In Nigerian Philosophy of Education, it is believed that education is a pivot for national development and all round development of an individual. In this end, the formulation of ideas, their integration for National development and the interaction of persons and ideas are all aspects of education (Federal Republic of Nigeria 2004). The role of education in the development of an individual and the society at large cannot be overemphasized. Education is not only a veritable tool for the transmission of norms and values to the younger generations but also a tool for liberation from ignorance and high rate of docility. When teaching and learning improves, social vices shall reduce and the communities and the larger society shall enjoy peaceful co-existence whose values cannot be overemphasized.

Counselling and moral education has always been a perennial aim of education that enables the students in enriching their perspective and promoting attitude towards resolving educational, vocational and personal problems. Fuster (2002) opined that the goals of counselling as facilitating behaviour change, enhancing coping skills, promoting decision-making, improving relationships and 
facilitating the client's potential. It is a personalized and individualised process for helping the individual to learn and acquire habits, skills, attitudes and interests which make him a normally adjusted being. Therefore, it is evident that the process and goals of counselling is to help the student move towards a greater level of self understanding.

The need for counselling and moral education in modern times has increased because of the multiplicity of problems that the individuals have to face in the various domains of life. The adolescent children may then inadvertently and unconsciously respond with the problems. They may feel disempowered and overwhelmed by the current system of education. In this rapidly moving complex society, the students are struggling for the better adjustment and existence. If they are not getting proper guidance they may engage in anti-social activities. Therefore it becomes pertinent that they catch them young because the age of the students during adolescence is sensitive and highly inflammable.

Counselling and moral education is not a quality which human beings acquire automatically, it entails directing human energies toward constructive social goals which has to be instilled by training and education so that a set of values may be formed. Thus the whole person is prepared for participation in the moral institutions with a proper sense of conscience, polity, law and economy. It implants in each individual such dispositions as shall enable them to live and work harmoniously with others, both in the present school premises and for the future, and on every level of human interaction (Charles 1963).

Counselling and moral education is a very important and inevitable tool which could avert the condition of disharmony in society. Moral education is universal and essential to every human culture. As we all know that any society without a modicum of morality must collapse. In this sense, morality is the observance of rules for the harmonious adjustment of the interests of the individual to those of others in society (Wiredu 1992). According to Whiteley (1982), morality is social in a more fundamental sense, as an outline of norms of behaviour operative in a community. To this end, life in a human community is possible, only if there is a certain level of friendliness, mutual aid and rules for settling issues. Without these facilities, a society cannot survive or exist at all.

\section{Conclusion}

There is an increasing trend of agitations in nearly all the geo-political zone of the federation which have led to the operation of several militia groups converting our youth into hooligans, terrorists, oil bunkering, hijackers, vandals etc across regions and boundaries of the federation. It is obvious that the shortfalls of students' education which has made them hostile in the society are seen mainly in the inability of the various governments and educational sectors to consistently and institutionally moderate the conduct of the youths in view of civilized conduct. To this end, the problem of agitations could be seen as lack of counselling and moral education on the part of the youth. Therefore there is a striking and urgent need for government to consider counselling and moral education as a panacea if the increasing trend of agitations must be curbed.

\section{Recommendations}

The following are the recommended in curbing the increasing trend of agitations in Nigeria.

- Government should make counselling and moral education an integral part of the education process and that more time and status should be allocated.

- Government should support counselling and moral education practically by providing and making funds available.

- Parents also should be included in guidance and counselling programme through giving them progressive report of their children.

- The inculcation of moral value should not rely on the government alone; parents, teachers, religious leaders and community leaders are expected to contribute to the trend. 
Texila International Journal of Clinical Research

Volume 3, Issue 2, Dec 2016

- Youths should learn to identify pride in self-worth regardless of race, colour, or creed, discrimination will disappear from society when persons are judged not by skin colour, ethnic groups, or the class to which they belong, but by their ability and integrity.

- Government should provide the right education and training that will ensure the possession of a stable skill suitable for youth to enhance youth participation in social orderliness and national development.

\section{References}

[1] Atwater, E. (1988). Adolescence. (2nd Ed). New Jersey: Prentice Hall, Inc.

[2] Azaiki, S. (2007). Inequities in Nigerian Politics. Ibadan: Y-Books.

[3] Biswalo, (1996). An introduction to guidance and Counselling Diverse Africa Contexts. Dare Salaam: Dare salaam University Press.

[4] Boyle, P. (2010). 'Nigeria's Taliban Enigma'. BBC News, 31 July 2009, http://news.bbc.co.uk/2/hi/8172270.stm (accessed 8 July 2010).

[5] Charles, E. C. (1963). Moral Education in family, school and church, (Philadelphia: The West Minster Press, p.60. 2.

[6] Corey G. (1988). Issues and Ethics in the Helping professions. Pacific Grove, CA, Brooks Cole.

[7] Corey, G. (1991). Theory and Practice of Counselling and Psychotherapy. 4th ed. Pacific Grove. California: Brooks/Cole Publishing Company.

[8] Dollard, J. Miller, N. E, Doob, L.W, Mowrer, O.H, Sears, R.(1939). Frustration and Aggression. New Haven, Yale University Press.

[9] Egbe, M. E. (2004). The State and Civil Society in Nigeria: Study of the Movement for the Survival for the Ogoni People (MOSOP) Lagos: NIIA Occasional Papers.

[10] Egbo, A.C. (2013). Development of Guidance and counselling, Enugu; Joe best publishers.

[11] Fafunwa, B. (1976). History of Education in Nigeria. London: George Allen and Unwin Ltd.

[12] Federal Ministry of Education (2004). National policy on Education, Lagos federal Government printers.

[13] Ile, C. \& Akukwe, C. (2001). Niger delta, Nigeria, Issues, Challenges and opportunities for equitable development. Retrieved on 27/10/2011 from http://nigeriaworld.com/feature/article/niger-delta.html

[14] Kelly (2008). Bringing peace to the Niger Delta. www.usip.org/pubs/unpeacebriefings_niger_delta html.

[15] Midlarsky, M. (1975). On War: Political Violence in the International System, New York, Free Press.

[16] Mutie, E. K. \& Ndambuki, P. (2004). Guidance and Counselling for Schools and Colleges. Nairobi: Oxford University Press.

[17] National Bureau of Statistics (2006). Federal Republic of Nigeria 2006 Population Census. accessed 26/10/2011 from http://www.nigerianstat.gov.ng/nbsapps/Connections/Pop2006.pdf

[18] Nigeria Dangerous Slide: The New York Times 2012 (Retrieved 0n the 20 April 2013)

[19] Ojukwu C. C. (2009). Igbo Man’s Burden Abeokuta: EMI Publications.

[20] Okoye, A.U. (2010) Counselling in the industrial setting Visa Vis industrial relation. Aroka; Erudite publishers.

[21] Omipidan, I. (2013). Total War. www.sunnewspaper online 19 May 2013 (Retrieved on 22 May 2013

[22] Omoregbe, J. (2000). Ethics: A Systematic and Historical Study. Lagos: Joja Educational Research and Publishers.

[23] Uzodima, E. (2014). Biafra Zionists Federation attempts to seize Enugu radio station, kills police officer. Daily post 5 June.

[24] Whitely, C. H. (1982). The Justification of Moral Philosophy. Vol. 57, No. 222

[25] Wiredu, K. (1992). The Moral Foundations of an African Culture: In Kwasi Wiredu and Kwame Gyekye (eds) Person and Community Ghanaian Philosophical Studies 1. Washington D.C: The Council for Research in Values and Philosophy. 